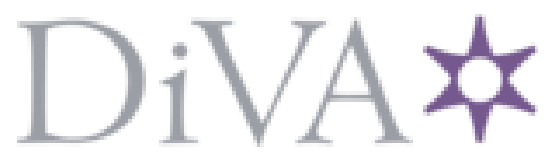

http://www.diva-portal.org

This is the published version of a paper published in Freshwater Biology.

Citation for the original published paper (version of record):

Malm-Renöfält, B., Nilsson, C. (2008)

Landscape scale effects of disturbance on riparian vegetation.

Freshwater Biology, 53(1 1): 2244-2255

http://dx.doi.org/10.1111/j.1365-2427.2008.02057.x

Access to the published version may require subscription.

N.B. When citing this work, cite the original published paper.

Permanent link to this version:

http://urn.kb.se/resolve?urn=urn:nbn:se:umu:diva-1 1364 


\title{
Landscape scale effects of disturbance on riparian vegetation
}

\author{
BIRGITTA MALM RENÖFÄLT AND CHRISTER NILSSON \\ Landscape Ecology Group, Department of Ecology and Environmental Science, Uminova Science Park, Umeå University, SE-901 \\ 87 Umeå, Sweden
}

\section{SUMMARY}

1. Differing responses in riparian species richness and composition to disturbance have been reported as a possible explanation for the differences along and between rivers. This paper explores the role of physical disturbance in shaping landscape-scale patterns of species distribution in riparian vegetation along a free-flowing river in northern Sweden.

2. To test whether sensitivity to disturbance varies across large landscapes, we experimentally disturbed riparian vegetation along an entire, free-flowing river by scouring the soil and the vegetation turf, cutting vegetation, applying waterborne plant litter, and after a period of recovery we measured vegetation responses. The experiment was repeated for two consecutive years.

3. We found no significant effect of disturbance on species composition, but all three forms of disturbance significantly reduced species richness. There was no downstream variation in community responses to disturbance but morphological groups of species responded differently to different kinds of disturbance. Graminoids were most resistant, suppressed only by litter burial. All forms of disturbance except cutting reduced the density of herbaceous species, and species density of trees + shrubs and dwarf shrubs was negatively affected by both scouring and cutting. We also evaluated the effects of disturbance in relation to varying levels of species richness. In nearly all cases, responses were significantly negatively correlated with control plot species richness, and relative responses indicated that species-rich plots were less resistant to scouring and cutting. 4. Our results suggest that although all disturbance treatments had an effect on species richness, variation in sensitivity to disturbance is not the most important factor shaping landscape-scale patterns of riparian plant species richness along rivers.

Keywords: disturbance, experimental, landscape patterns, riparian vegetation, river

\section{Introduction}

Free-flowing rivers generally have species-rich riparian vegetation (Junk, Bayley \& Sparks, 1989; Tabacchi, Planty-Tabacchi \& Décamps, 1990; Nilsson et al., 1994; Planty-Tabacchi et al., 1996), and in some rivers the highest densities of plant species have been found in the

Correspondence: Birgitta Malm Renöfält, Landscape Ecology

Group, Department of Ecology and Environmental Science,

Uminova Science Park, Umeå University, SE-901 87 Umeå,

Sweden.

E-mail: birgitta.renofalt@emg.umu.se middle reaches (e.g. Nilsson et al., 1989, 1991a; PlantyTabacchi et al., 1996). There is so far no unequivocal explanation for this humped pattern, but a number of variables have been suggested, such as substrate heterogeneity, disturbance, plant dispersal, and a mid-domain effect (Nilsson et al., 1989, 1994; Ward, 1998; Dunn, Colwell \& Nilsson, 2006). The mid-domain effect implies that physiographical and physiological boundaries in relation to range-size distributions lead to mid-domain richness peaks even without environmental gradients (Colwell \& Lees, 2000). However, Renöfält, Merritt \& Nilsson (2007) found the temporal variability in patterns of species richness along a 


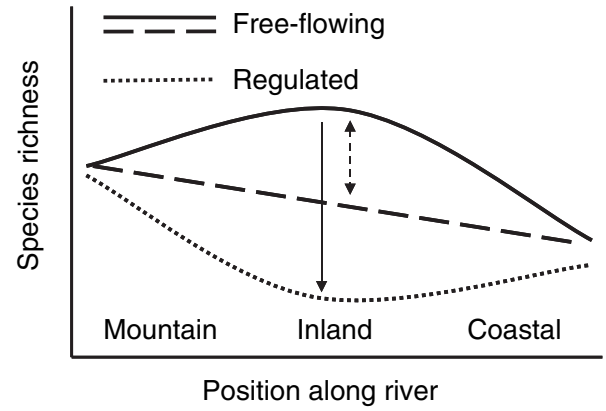

Fig. 1 Conceptual illustration of reported downstream patterns of riparian vascular plant species richness in free-flowing (solid and dashed lines) and regulated (dotted line) rivers in northern Sweden. The dashed arrow indicates the window in which landscape-scale patterns of species richness have been observed to vary in the free-flowing Vindel River. This variability, with highest dynamism in middle reaches, is largely governed by the intensity and magnitude of flood events in the sense that periods of minor floods foster the quadratic pattern whereas single, major floods make the line flat (Renöfält et al., 2007). Consistent with this, the species richness pattern in regulated rivers, based on data from four such rivers, is inverted relative to that of free-flowing ones, with the largest difference (interpreted as "species loss") in inland reaches (solid arrow) (Nilsson \& Jansson, 1995).

free-flowing river over a period of three decades to be highly dynamic. In some years, the pattern was indeed quadratic with the mid-reaches showing most species but in others it instead decreased linearly towards the coast (Fig. 1). This dynamism rules out the mid-domain effect as a single cause. The observed downstream variability in species distribution was related to periods of large, long-lasting floods, suggesting that major flood disturbance can trigger temporal shifts in species distribution at the scale of landscapes. Nilsson \& Jansson (1995) corroborated this result by demonstrating that vascular plant diversity in four rivers with cascades of reservoirs in northern Sweden exhibits a downstream pattern that is almost inverted relative to that of free-flowing ones, with lowest numbers in the middle reaches. In other words, the mid reaches appear to be the most sensitive to human perturbation (Fig. 1). The reasons for this pattern are seemingly complex. Nilsson \& Jansson (1995) discussed changes in disturbance regimes and obstructions to hydrochory but ruled out each of these as single causes.

The riparian corridor of free-flowing rivers is subjected to a wide range of natural disturbances. (1) Mechanical scouring is one example, implying that soils are scoured both by floodwater and by waterborne debris. (2) In boreal riparian systems, moving ice affects geomorphology and vegetation, ranging from ice scars (Polzin \& Rood, 2006) to ice-jam flooding (Church, 2002) and large pieces of ice cause tree and shrub damage and mortality (Filip, Bryant \& Parks, 1989). (3) Flooding in boreal, free-flowing rivers results in erosion, transport and deposition of litter and sediments (Xiong et al., 2001). Accumulation of litter and sediments may influence vegetation through burial and changes in light availability (Tilman, 1993), changes in temperature and moisture (Green \& Kauffman, 1995), transport and deposition of seeds (Nilsson \& Grelsson, 1990; Vogt, Rasran \& Jensen, 2007) and nutrient supply (Olde Venterink et al., 2006). Flood disturbance is generally thought of as the primary driver of riparian plant diversity and distribution (cf. Junk et al., 1989; Poff et al., 1997; Tockner, Malard \& Ward, 2000). Environmental gradients created by water movements shift in space and time, providing niches for species to re-assemble and coexist, resulting in dynamic, non-equilibrium, riparian plant communities. Species that cannot coexist in stable environments are able to withstand superior competitors in disturbed environments, giving rise to one of the most diverse terrestrial habitats on earth (Naiman, Décamps \& Pollock, 1993). Natural flood disturbance dynamics in northern Swedish rivers is relatively predictable in timing and magnitude of flood and drought events. If disturbance regimes are heavily altered, the structure and composition of riparian vegetation will change (Shafroth, Stromberg \& Patten, 2002). One explanation for abundance shifts after disturbance is the hypothesis of "competitive change" (Suding \& Goldberg, 2001), which predicts that species can modify their competitive responses when subjected to disturbance. If disturbance affects different species groups differently, this will lead to altered community assemblages and dynamics.

This paper presents a study designed to test whether the effect of disturbance on species richness and composition of riparian vegetation along the freeflowing boreal Vindel River, located in northern Sweden, shows geographic variability consistent with the observations of species richness patterns made after large floods and flow regulation (Fig. 1). We tested this hypothesis by evaluating the effects of three types of disturbance on species richness and species composition: (1) scouring of soil and vegetation turf; (2) vegetation cutting and (3) addition of 
waterborne plant litter on river reaches located along the entire river. We also tested the effect on morphological species groups, thus separating between trees + shrubs, dwarf shrubs, herbs and graminoids in order to evaluate whether groups differed in their ability to resist disturbance, and whether their responses differed with type of disturbance. Furthermore, we asked whether there is any correlation between species richness and the resilience of vegetation to disturbance. For example, can the inverted pattern of species richness found in the mid reaches of regulated rivers result from a proportionally greater loss in initially more species-rich areas? Finally, we assessed whether responses to disturbance correlate with environmental attributes and species richness of the reach.

\section{Methods}

\section{Study site}

The study was made in the free-flowing Vindel River in northern Sweden (Fig. 2). This 455-km long river originates in the mountains between Sweden and Norway and empties into the Ume River about $40 \mathrm{~km}$ upstream from the Gulf of Bothnia. Fluctuation in water level includes spring flooding followed by subsequent lowering during summer and winter (Nilsson et al., 1994), sometimes interrupted by smaller autumn peaks due to rainfall. Natural discharge at the confluence with the Ume River varies between 16 and $1800 \mathrm{~m}^{3} \mathrm{~s}^{-1}$ depending on season, with an annual mean of $200 \mathrm{~m}^{3} \mathrm{~s}^{-1}$. Variation in mean annual flows among years is small (coefficient of variation close to the river mouth: $15.9 \%$ for the period 1911-1988). Variation in magnitude and duration of the flood peak shows more variability. Floods with recurrence intervals of 2-3 years $\left(\sim 1000 \mathrm{~m}^{3} \mathrm{~s}^{-1}\right)$ typically inundate the entire riparian zone (Renöfält, Jansson \& Nilsson, 2005a). In summer, riparian zones have an average width of $30 \mathrm{~m}$ on each side of the river (Nilsson et al., 1991b), and an additional 10-20-m wide zone on each side is exposed during extreme low water in winter. During winter, this zone is covered by a $50-100-\mathrm{cm}$ thick layer of ice. The geomorphology of the river varies from mountain regions dominated by coarse-grade till, to coastal regions mainly consisting of fine sediments (Sundborg, Elfström \& Rudberg, 1980; Nilsson et al., 1994). The riparian vegetation along the Vindel River shows a lateral zonation due to the even slope of the river margin, with forest communities in the higher elevated part, succeeded by shrub vegetation, to herbaceous communities on the lower levels closest to the channel (Fig. 3a, Nilsson, 1999).

\section{Fieldwork}

This experiment was conducted during two consecutive years, 1997 and 1998. The experimental plots were disturbed in late June in both years, after recession of the spring flood peak when vegetation had started to emerge after winter. Vegetation was then left to recover over the peak of the growing season and

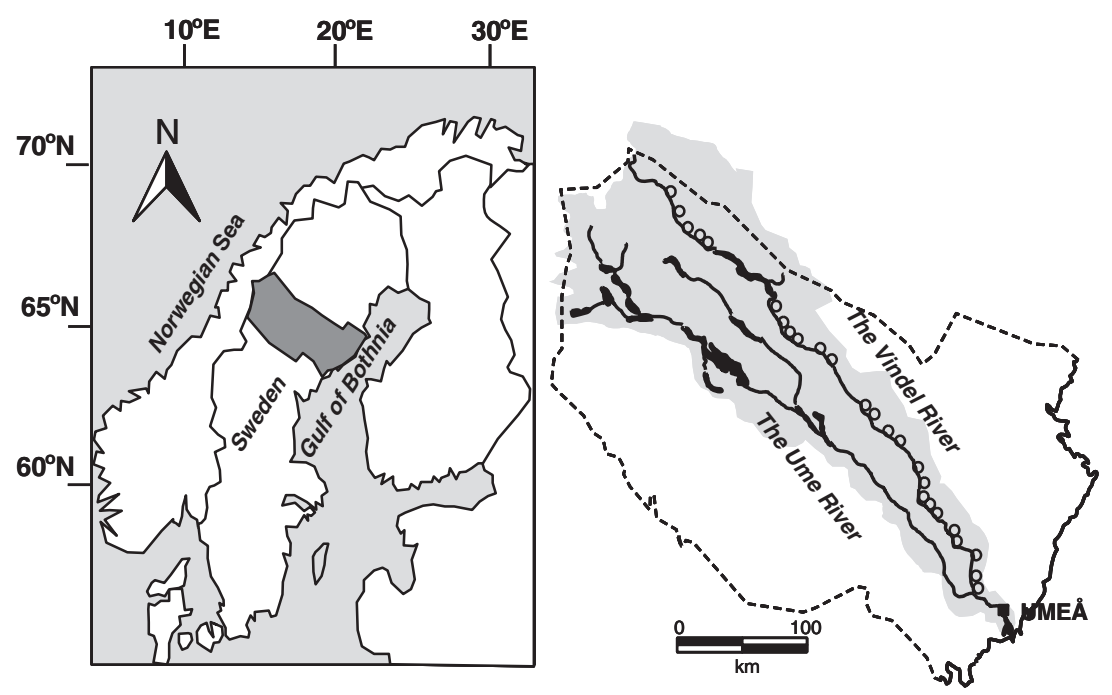

Fig. 2 The Vindel River in northern Sweden. Circles indicate the location of the 25 studied river reaches, each one located in the transition zone between a turbulent and a tranquil reach. 
Fig. 3 (a) Cross-section of the riparian zone. The riparian vegetation along the Vindel River shows a distinct lateral zonation from higher to lower elevations, with forest communities in the higher elevated part, succeeded by shrub vegetation, to herbaceous communities on the lower levels closest to the channel. Plots were located in the Alnus zone. (b) Outline of the experimental setup. Four replicates of three blocks were located along a $100-\mathrm{m}$ stretch in the turbulent section and four replicates of two blocks along a 100-m wide stretch of the tranquil section. Blocks in the turbulent section consisted of randomly arranged plots; two types of disturbance (scouring and cutting) and a control plot. Blocks in the tranquil section consisted of one plot with litter addition and one control plot. (a)

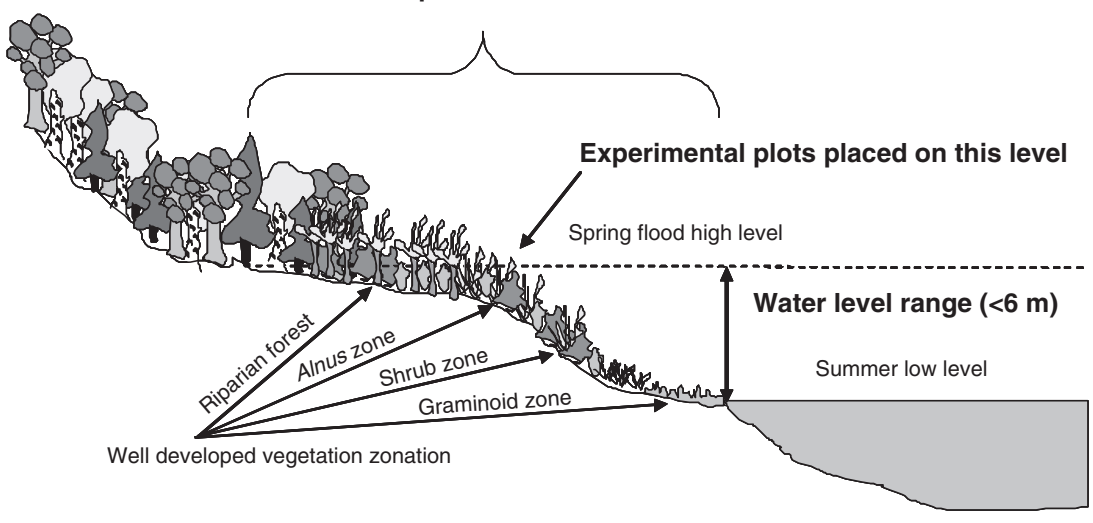

(b)

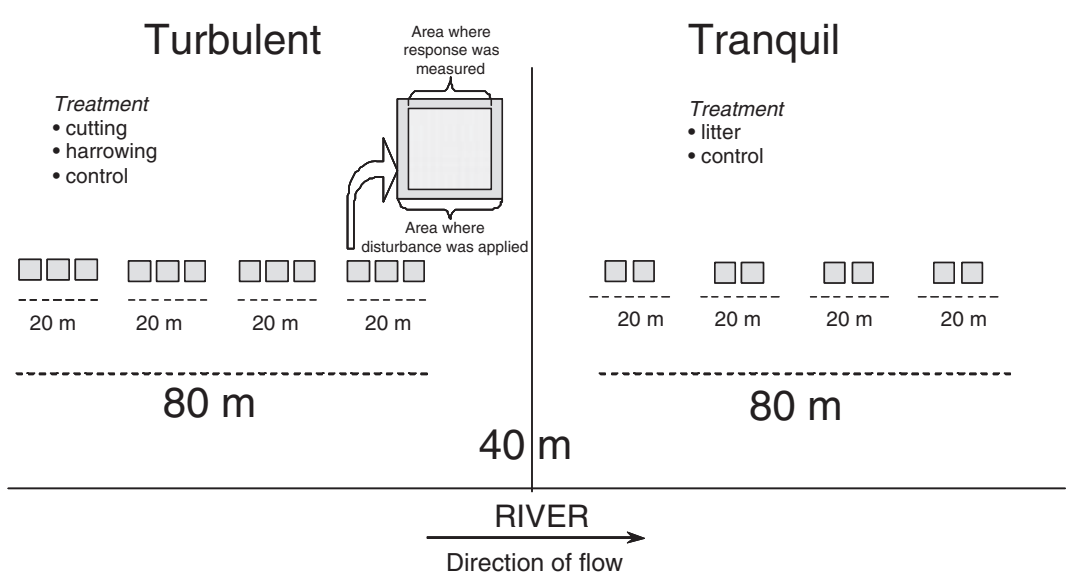

was inventoried in mid August in both years. Twentyfive river reaches were identified along the river and georeferenced relative to the headwaters. Although the magnitude of flooding increases downstream (Sundborg et al., 1980), we tried to minimize the natural spatial variation in flood impact. First, all reaches were located in the transition area between turbulent and tranquil water (i.e. at the base of rapids), assuming that the vegetation in such areas is subjected to a similar, current-related disturbance regime at all sites along the river. Secondly, all treatments were positioned in the alder [Alnus incana (L.) Moench] fringe of the riverbank or, if an alder fringe was lacking, positioned at corresponding elevations (Fig. 3a). This elevation is flooded for about $2-3$ weeks each year during spring (May-June) and is also occasionally flooded during infrequent summer and autumn rain storms.

At each reach a block of treatments was established (Fig. 3b). Four replicates of the blocks were located along a 100-m stretch in the turbulent section and four others along a $100-\mathrm{m}$ wide stretch of the tranquil section. Blocks in the turbulent section consisted of three randomly arranged plots; two types of disturbance (scouring and cutting) and a control plot. Blocks in the tranquil section consisted of one plot with litter addition and one control plot. Disturbance created by scouring was located in turbulent parts of the river since these are often narrow with fast-flowing water and therefore naturally exposed to high levels of flood and ice scouring. The experiment on litter accumulation was located in the tranquil part of the transition area since litter and seeds are mainly deposited in backwater reaches downstream from rapids (Nilsson \& Grelsson, 1990; Johansson \& Nilsson, 1993).

Each plot encompassed an area of $0.5 \times 0.5 \mathrm{~m}$, but to avoid edge effects all disturbances were applied to an area of $0.8 \times 0.8 \mathrm{~m}$ with the $0.5 \times 0.5-\mathrm{m}$ plot located in the centre of the disturbed area (Fig. 3b). Plots were positioned along the riverbank with their centres 
$6.5 \mathrm{~m}$ apart, leaving a 20-m wide margin at each side closest to the riparian transition. In this transition part four undisturbed plots were positioned, $6.5 \mathrm{~m}$ apart. These plots were used to measure small-scale dissimilarity in vegetation composition in the riparian corridor.

Scouring was performed by raking (10 replicate strokes with a metal garden rake at each site), cutting implied that all aboveground vegetation (approximately $1 \mathrm{~cm}$ above ground level) was cut and removed, and litter burial was carried out by evenly distributing $2.5 \mathrm{~kg}$ of partly dried, waterborne litter (room dry weight $=575 \mathrm{~g}$ ) from the lower reaches of the Vindel River on top of the emerging vegetation. The level of applied disturbance approximated to that of a flood with a recurrence interval of 2-3 years.

All experimental and control plots were inventoried for species presence or absence. Species nomenclature follows Krok \& Almquist (1994). The taxa Salix myrsinifolia Salisb. + S. phylicifolia L. were treated as one species as these species often hybridize. This was also the case for Carex juncella (Fr.) Th.Fr. + C. nigra (L.) Reichard. Hieracium L. spp., Taraxacum F. H. Wigg. spp. and Alchemilla L. spp. were identified only to genus level.

In addition, total species richness and environmental variables were recorded on the surrounding $200-\mathrm{m}$ river reach in 1998. Data collected included: river margin width (mean width of five measurements equally distributed along the reach); area (mean width of the five measurements $\times$ length of reach); riverbank height [height between the spring flood high, i.e. the highest level attained at least once every 2 years, and summer low levels (Fig. 3a) where the top of the riverbank was judged equivalent to the lower end of continuous occurrences of flood intolerant species such as Vaccinium myrtillus L., measured in middle of the reach]; substrate heterogeneity (number of substrates per reach); substrate fineness (substrates classified using the Wentworth grain sizes clay, silt, sand, gravel, pebbles, cobbles and boulders; Chorley, Schumm \& Sugden, 1984), supplemented by peat and bedrock (see Nilsson et al., 1991b for further details); substrate fineness ( $\Phi$ values calculated by weighing $\log _{2}$-transformed values of mean particle size by percentage composition of the river margin substrate; Wright et al., 1984; Nilsson et al., 1989) and percent cover of plants (trees + shrubs, dwarf shrubs, herbs and graminoids).

\section{Data analyses}

Dissimilarity in floristic composition between treated and control plots, and small-scale natural dissimilarity in floristic composition among undisturbed plots were tested using Jaccard's index of similarity (SI), which is calculated as

$$
\text { SI }=\text { all matches } /(\text { all matches }+ \text { all non-matches }) \text {, }
$$

where a match is any occurrence of the same species in the two plots or sites being compared and a nonmatch is an occurrence of a species only in one or the other plot. The obtained values range between 0 and 1 , where 0 means that all species in the paired plots are different, and 1 that they are all the same. The inverted similarity value expresses dissimilarity in floristic composition. A treatment effect for the reach was calculated as the mean dissimilarity between treatment and control of all four replicates. The treatment effect was compared with natural dissimilarity in floristic composition of the reach calculated as the mean dissimilarity among the four undisturbed control plots. The mean dissimilarity of the treatment-control pairs was compared with the mean dissimilarity of undisturbed plots using a pairedsample $t$-test. This analysis was made for each of the treatments.

To test if the effects of disturbance on species composition varied along the river corridor and differed from the longitudinal pattern of natural dissimilarity in floristic composition, we related floristic dissimilarity between controls and treatments and floristic dissimilarity between control plots to distance along the river. All relationships were tested with linear and polynomial regressions. We tested whether the slopes of treatment effects differed from the slope of natural dissimilarity in floristic composition using analysis of covariance (ANCOVA).

The effect of disturbance on species richness was calculated as the difference in mean species richness between treated and control plots. We could not assess the pre-disturbance species richness of the treated plot since all treatments were carried out in spring, immediately after the recession of the spring flood peak, when the riparian vegetation had only begun to emerge after winter dormancy and accurate species richness levels could not be obtained. Therefore, we used species richness of control plots as an estimate of pre-disturbance plot species richness. We tested 
whether undisturbed vegetation differed in species richness between plots by comparing mean species richness of control plots 1 and 2 with mean species richness of control plots 3 and 4 . This was done for control plots in both tranquil and turbulent sections. We tested if species richness was significantly lowered by disturbance by comparing mean species richness of control plots with mean species richness of disturbed plots. We also tested the effects of disturbance between treatment and control plots separately for morphological groups; trees + shrubs, dwarf shrubs, herbs and graminoids (1998 data only). All of these tests were conducted using paired-sample $t$-tests.

To test if the effects of disturbance on species richness varied along the river corridor we related the difference in species richness between treated and control plots to the location along the river and applied linear and polynomial regression analyses. We also tested using ANCOVA if the relationship between species richness and location, both on the treated and the control plots differed from each other. In addition, we evaluated the relationship between the effect of disturbance in terms of species loss (absolute and relative) and control plot species richness using linear and polynomial regression analyses. We also correlated disturbance effects with environmental variables [river margin width, river margin height, substrate heterogeneity, substrate and percent cover of plants (trees + shrubs, dwarf shrubs, herbs, and graminoids)] and species richness of the reach. All statistical tests were made using the statistical software sPSS version 11.0 (SPSS Inc., Chicago, IL, USA) and Sigmaplot 7.0.

\section{Results}

\section{Effects on floristic composition}

Floristic composition was not affected by disturbance. Mean dissimilarity between treatment and control plots and mean dissimilarity among control plots only were not significantly different for any of the treatments. Natural dissimilarity in floristic composition and effects of disturbance did not show significant downstream patterns for any of the years $(P>0.05$, linear and polynomial regressions). In addition, there was no significant difference between the regression lines of the natural heterogeneity versus location, and of the treatment-control versus location for any of the treatments $(P>0.05$, ANCOVA, two-tailed probability).

\section{Effects on species richness}

In several cases, species richness was affected by disturbance. Species richness in the disturbed plots was significantly lower than in control plots for all treatments (Table 1). When species were divided into morphological groups and treated plots were tested against control plots, the effect varied with treatment (Table 2). Scouring had a significant effect on

Table 1. Difference in species richness between pairs of treated and control plots (paired sample $t$-test, two-tailed probability; significant differences boldfaced) along the Vindel River

\begin{tabular}{|c|c|c|c|c|c|}
\hline \multirow[b]{2}{*}{ Treatment } & \multicolumn{2}{|c|}{ Treated plots } & \multicolumn{2}{|c|}{ Control plots } & \multirow[b]{2}{*}{$P$} \\
\hline & Mean & $\mathrm{SD}$ & Mean & SD & \\
\hline \multicolumn{6}{|l|}{1997} \\
\hline \multicolumn{6}{|l|}{ Scouring } \\
\hline $1997(n=25)$ & 10.35 & 3.08 & 12.11 & 3.51 & 0.002 \\
\hline $1998(n=25)$ & 9.53 & 3.16 & 10.83 & 3.06 & 0.007 \\
\hline \multicolumn{6}{|l|}{ Cutting } \\
\hline $1997(n=25)$ & 10.77 & 2.48 & 12.11 & 3.51 & 0.003 \\
\hline $1998(n=25)$ & 9.63 & 3.39 & 10.83 & 3.06 & $<0.001$ \\
\hline \multicolumn{6}{|l|}{ Litter deposition } \\
\hline $1997(n=25)$ & 10.12 & 3.33 & 11.83 & 3.18 & 0.008 \\
\hline $1998(n=24)$ & 8.08 & 2.48 & 9.78 & 2.95 & 0.001 \\
\hline
\end{tabular}

Table 2 Differences in absolute species richness for morphological groups between treated and control plots (paired sample $t$-test, two-tailed probability; significant differences boldfaced) along the Vindel River

\begin{tabular}{|c|c|c|c|c|c|}
\hline \multirow[b]{2}{*}{ Treatment } & \multicolumn{2}{|c|}{ Treated plots } & \multicolumn{2}{|c|}{ Control plots } & \multirow[b]{2}{*}{$P$} \\
\hline & Mean & $\mathrm{SD}$ & Mean & $\mathrm{SD}$ & \\
\hline \multicolumn{6}{|l|}{ Scouring } \\
\hline Trees + shrubs & 0.43 & 0.42 & 0.66 & 0.46 & 0.006 \\
\hline Dwarf shrubs & 0.94 & 0.75 & 1.14 & 0.88 & 0.043 \\
\hline Herbs & 5.06 & 2.33 & 5.87 & 2.46 & 0.004 \\
\hline Graminoids & 2.90 & 1.03 & 3.16 & 1.00 & 0.243 \\
\hline \multicolumn{6}{|l|}{ Cutting } \\
\hline Trees + shrubs & 0.38 & 0.37 & 0.66 & 0.46 & 0.003 \\
\hline Dwarf shrubs & 0.73 & 0.75 & 1.14 & 0.88 & $<0.001$ \\
\hline Herbs & 5.47 & 2.36 & 5.87 & 2.46 & 0.066 \\
\hline Graminoids & 2.85 & 0.84 & 3.16 & 1.00 & 0.098 \\
\hline \multicolumn{6}{|l|}{ Litter addition } \\
\hline Trees + shrubs & 0.52 & 0.38 & 0.67 & 0.44 & 0.164 \\
\hline Dwarf shrubs & 0.51 & 0.70 & 0.76 & 0.89 & 0.062 \\
\hline Herbs & 4.61 & 2.21 & 5.47 & 2.17 & 0.009 \\
\hline Graminoids & 2.27 & 0.79 & 3.16 & 1.00 & $<0.001$ \\
\hline
\end{tabular}

Data stem from 1998 
trees + shrubs and herbs, but not on graminoids. Cutting reduced numbers of tree + shrub species but numbers of herbs and graminoids were not significantly reduced. The effect of litter addition was opposite to that of cutting, with a significant decrease of herb and graminoid species richness, but not of tree + shrub species richness. Species richness did not differ among control plots (turbulent section: $n=25$, $P>0.05$, tranquil section: $n=25, P>0.05)$, and the effect of disturbance did not vary along the river $(P>0.05$, linear and polynomial regressions) for any treatment, except for litter addition in 1997 which had a significantly increased effect downstream $\left(r^{2}=0.60\right.$, $P=0.001$ ) (Fig. 4). There was no significant difference along the river between species richness of control and treatment plots for any of the treatments $(P>0.05$, ANCOVA, two-tailed probability).
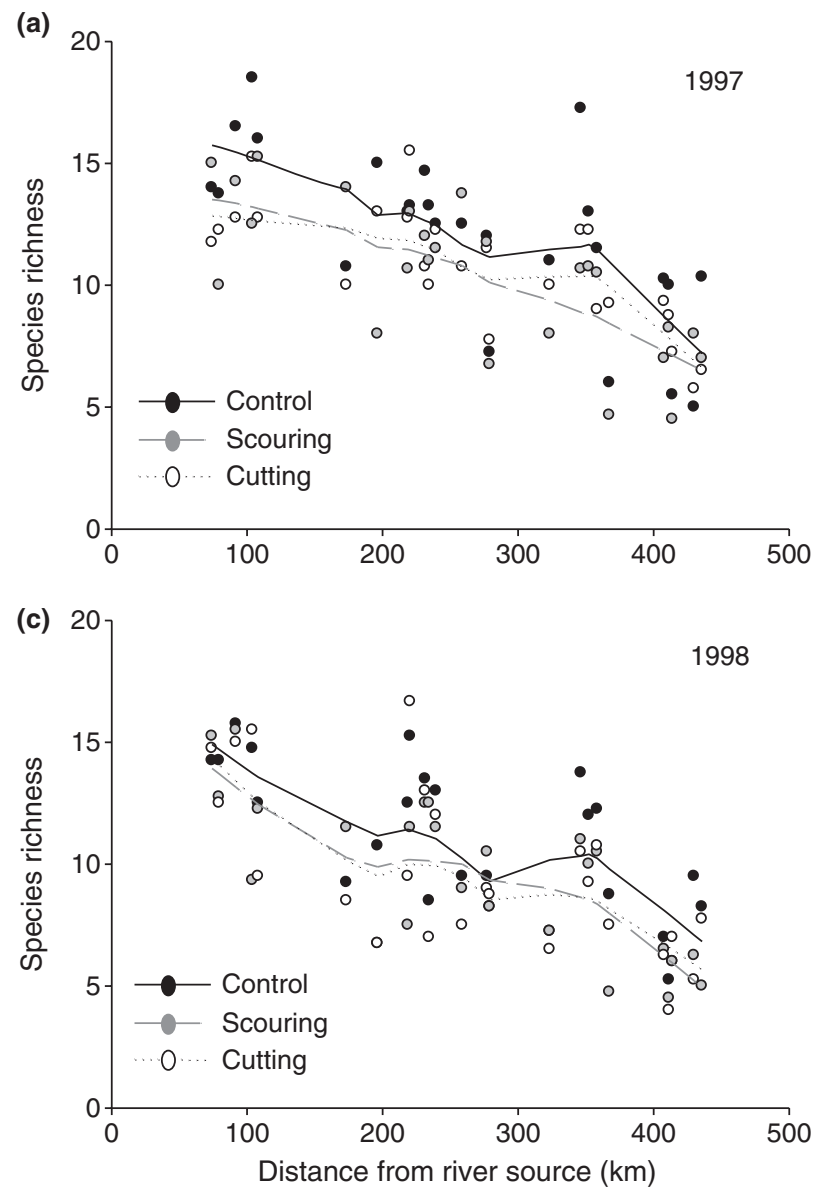

The absolute effects of disturbance were significantly positively correlated with control plot species richness for all treatments in 1997 (Fig. 5a, c and e; scouring: $r^{2}=0.27, P=0.0072$, cutting: $r^{2}=0.52$, $P \leq 0.001$, litter addition: $r^{2}=0.16, P=0.044$ ) with more species lost in plots with high species richness. In 1998, the effects of scouring showed no significant relationship with species richness (Fig. $5 b, r^{2}=0.10$, $P>0.05)$, although the tendency was the same, with species-rich plots losing more species. The effects of cutting showed a significant quadratic relationship with species richness in 1998, with greatest effects at intermediate levels of species richness (Fig. $5 \mathrm{~d}$, $\left.R^{2}=0.28, P=0.027\right)$. The relationship between effects of litter addition and species richness was statistically significant and similar to that of 1997, with species-rich plots losing more species (Fig. $5 f, r^{2}=0.16, P=0.042$ ).

(b)

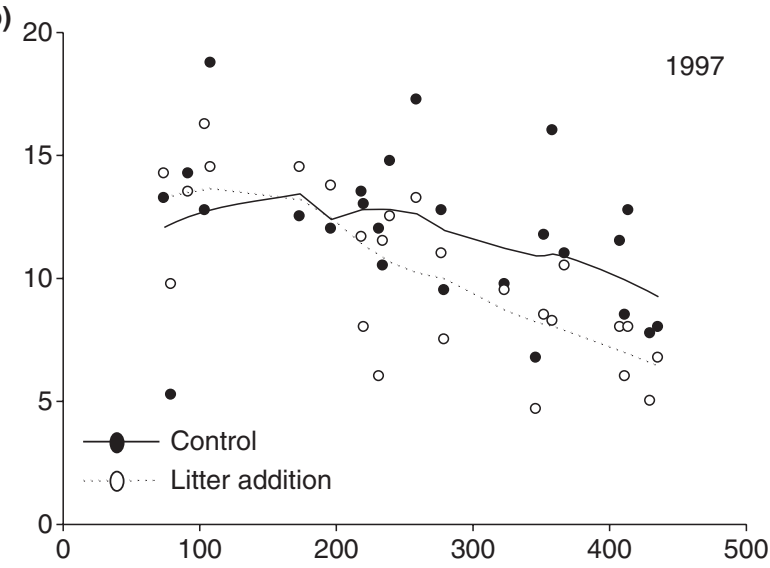

(d) 20

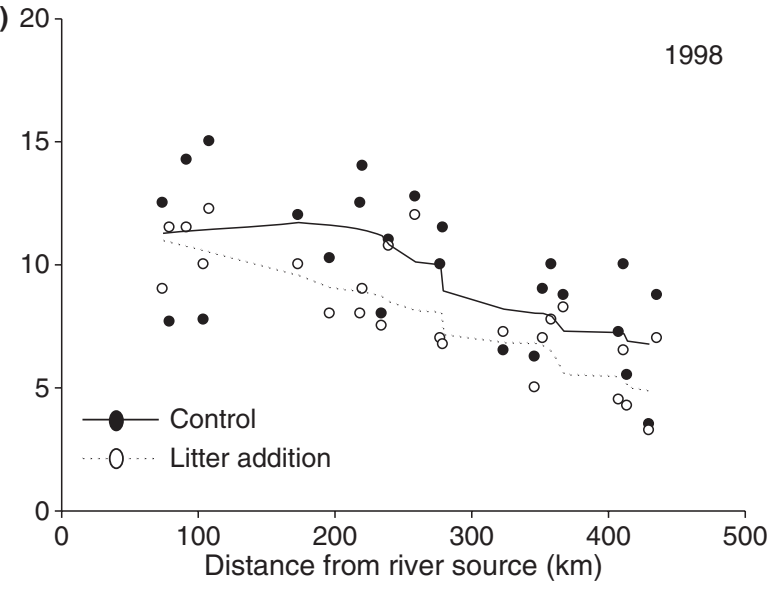

Fig. 4 Downstream patterns of species richness for (a) control, scouring and cutting in 1997, and (c) in 1998; (b) control and litter addition in 1997, and (d) in 1998. Treatments (a) and (c) were located to turbulent and treatments (b) and (d) to tranquil reaches of the Vindel River. There were no significant differences between the slopes of the relationships in any of the four diagrams $(P>0.05$, ANCOVA, two-tailed probability). 
(a)
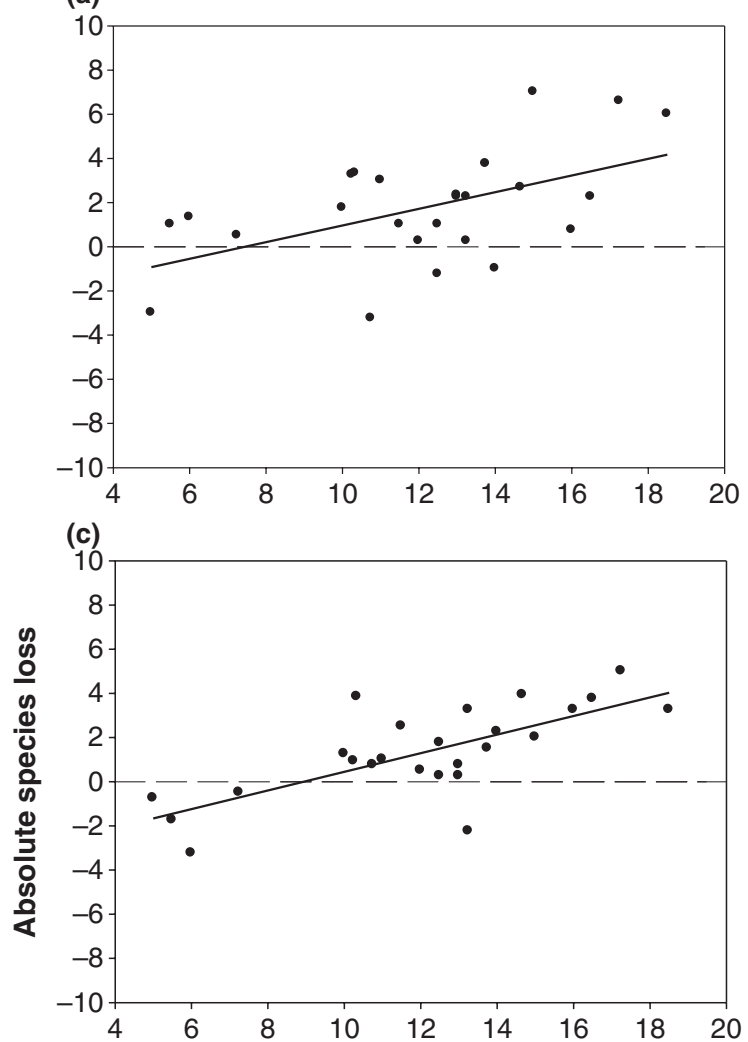

(e)

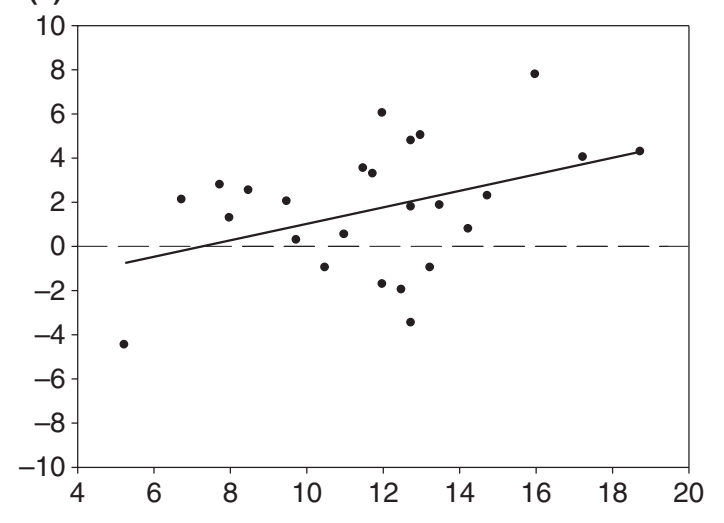

(b)

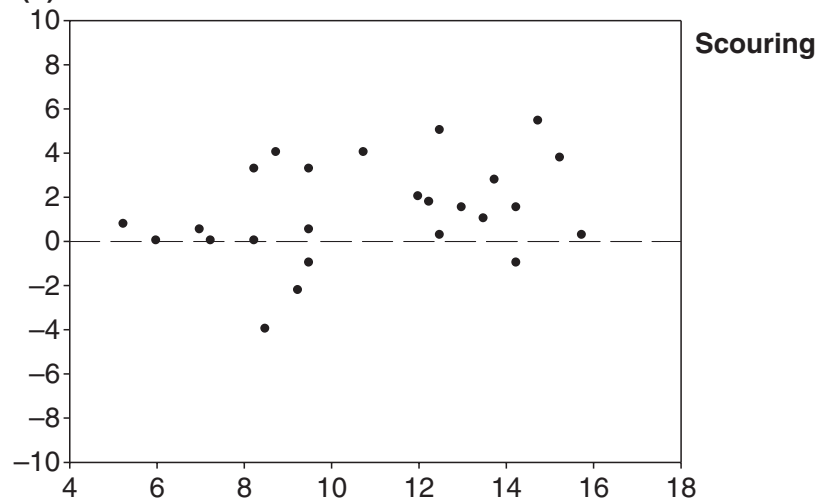

(d)

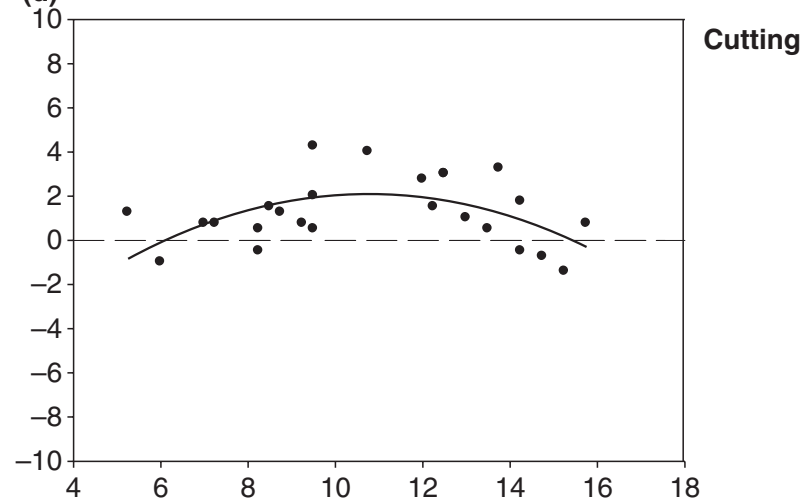

(f)

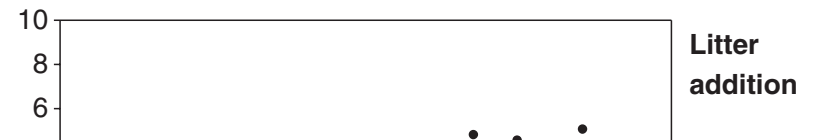

Fig. 5 Relationship between straight species loss and control plot species richness for (a) scouring of soil and vegetation turf in 1997, and (b) in 1998; (c) vegetation cutting in 1997, and (d) in 1998; (e) addition of waterborne plant litter in 1997, and (f) in 1998. Values above the dashed line represent species loss and values below species gain. Lines show significant linear and polynomial relationships (1997; scouring: $r^{2}=0.27, P=0.0072$, cutting: $r^{2}=0.52, P \leq 0.001$, litter addition: $r^{2}=0.16, P=0.044,1998$; cutting: $R^{2}=0.28, P=0.027$, litter addition: $\left.r^{2}=0.16, P=0.042\right)$.

Relative species loss showed a significant positive relationship with control plot species richness only for cutting (Fig. $6 c, r^{2}=0.46, P<0.001$ ); none of the other correlations between relative species loss and control plot species richness were statistically significant
(Fig. 6a, b, d-f, $P>0.05$ ). Both absolute and relative species losses following scouring were negatively correlated with field cover of the reach in 1998 (absolute: $r=-0.53, P=0.006$; relative: $r=-0.59$, $P=0.003$ ), but showed no correlation in 1997. The 
(a)

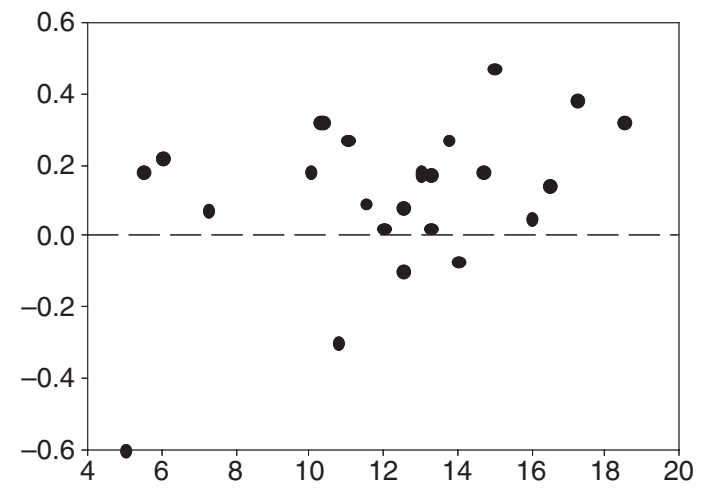

(c)

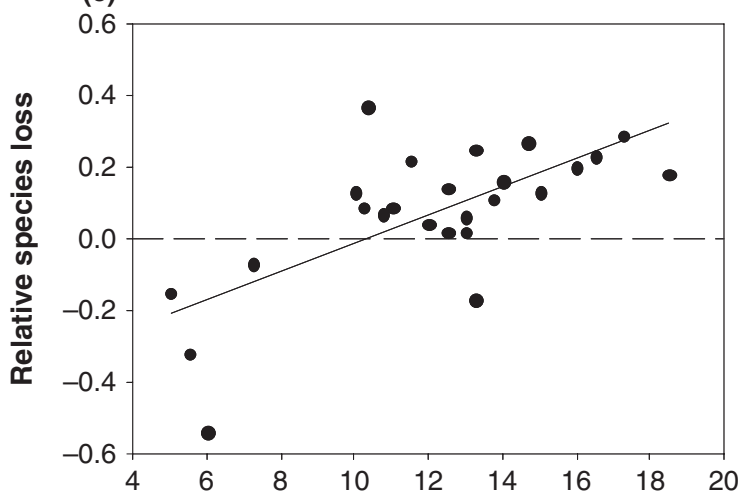

(e)

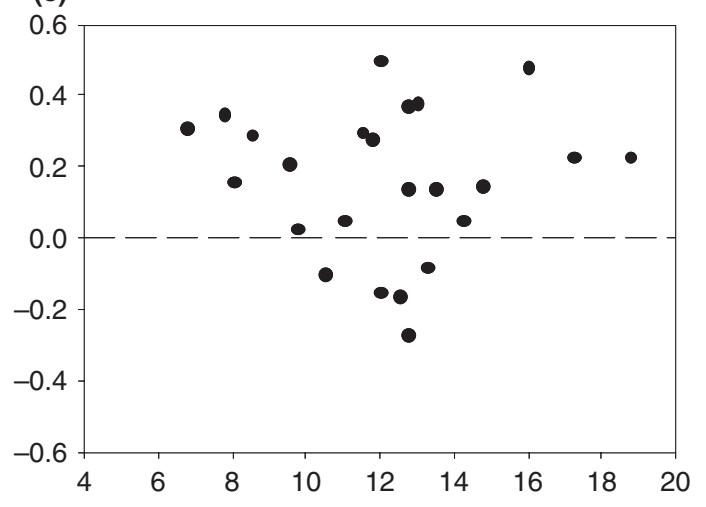

(b)

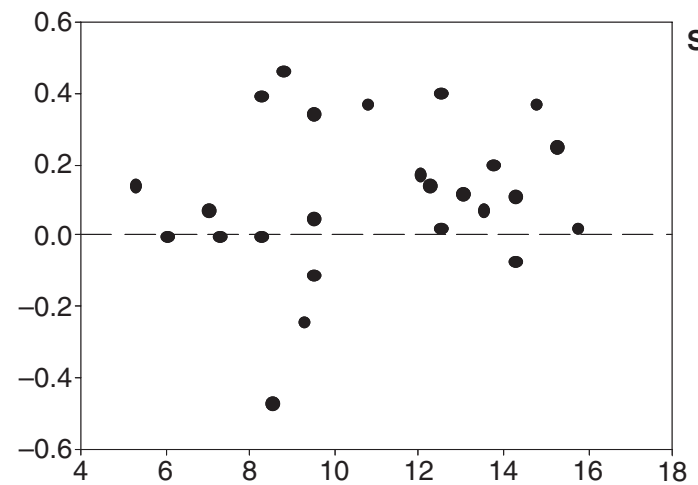

(d)

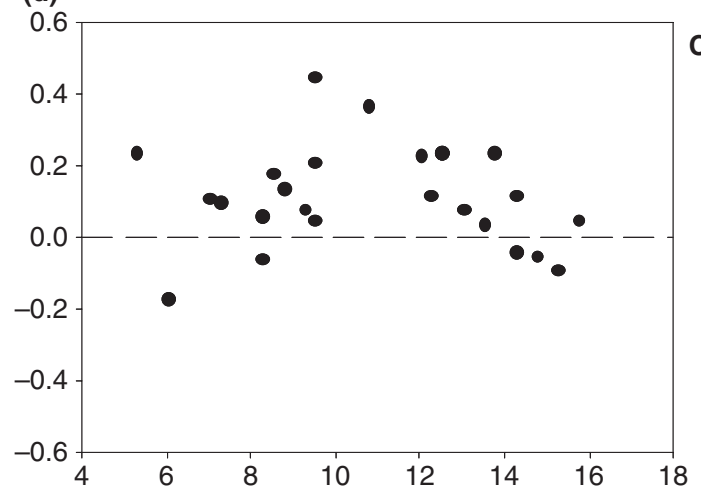

(f)

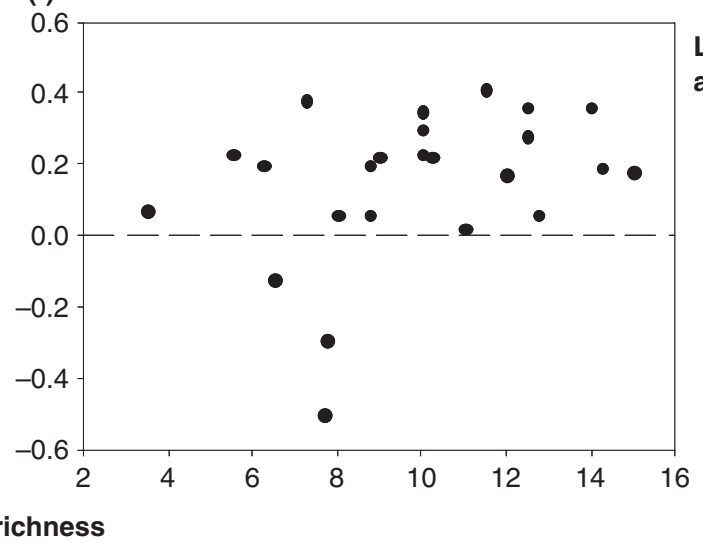

Cutting

Litter addition

Fig. 6 Relationship between relative species loss and control plot species richness for (a) scouring in 1997, and (b) in 1998; (c) cutting in 1997, and (d) in 1998; (e) litter addition in 1997, and (f) in 1998. Values above the dashed line represent species loss and values below species gain. The solid line shows a significant linear relationship for cutting in $1997\left(r^{2}=0.46, P<0.001\right)$.

relative effect of litter addition was significantly positively correlated with substrate fineness of the reach in 1997 ( $r=0.40, P=0.048)$. Neither straight nor relative species loss was correlated with any other environmental variable in any of the years $(P>0.05)$. The effects of disturbance were not correlated with reach species richness for any of the treatments, neither in 1997 nor in 1998 ( $P>0.05)$.

\section{Discussion}

On the basis of previous research findings, we assumed that riparian vegetation along rivers would show downstream variation in its response to various disturbances, and consequently that exploitation and management along rivers would have different impacts depending on their location. However, we 
did not find any clear support for our main hypothesis that vegetation in the middle reaches of the river is least resistant to disturbance. In fact, species richness was affected by all types of disturbance that were applied along the entire river, and treatment effects did not vary with downstream position (Fig. 4). Litter addition in 1997 formed an exception, but a raininduced flood that removed some of the added litter in the upper reaches of the river probably contributed to the observed trend of increasing effects downstream. One factor that might affect the interpretation of this study is the fact that the large-scale, humpshaped pattern of species richness is more unstable than was previously believed, and that long-lasting floods can even remove it, at least temporarily (Renöfält et al., 2007). The record flood in 1995, with a maximum discharge twice as high as the mean annual flood peak (Swedish Meteorological and Hydrological Institute), caused such a shift. Therefore, even though we operated on a smaller scale, the responses to our experimentally applied disturbance could have been hampered because the system was too recently disturbed.

The results do not support the hypothesis that disturbance would affect species composition (Suding \& Goldberg, 2001; Shafroth et al., 2002). Since riparian vegetation is naturally adapted to flood disturbance (Wintle \& Kirkpatrick, 2007), disturbance with a larger magnitude than ours could have been required to produce an effect. Also, natural dissimilarity in floristic composition was large at the reach level (mean dissimilarity $=0.70$ ), and probably large enough to mask any effect of disturbance on plant community composition. An alternative study approach would have been to sample the experimental plot in the previous growing season (i.e. before disturbance). However, annual species turnover along the Vindel River riparian corridor was also relatively high (mean dissimilarity of the control plots between 1997 and $1998=0.53$, inverted Jaccard's similarity index). This implies that the natural disturbances of riparian corridors most likely sustain high spatial and temporal heterogeneity in floristic composition at small scales. Studies comparing the vegetation dynamics at several scales could potentially provide more insight into these patterns.

Sparse vegetation would be expected to be more vulnerable to scouring than dense vegetation because the soil would be more exposed and fewer roots would be available to stabilize the soil (Pettit \& Naiman, 2007). The fact that the effect of scouring was negatively correlated with field cover of the reach in 1998 is therefore not surprising. However, the negative correlation between the effect of litter addition and substrate fineness in 1997 (the finer the substrate, the less the effect) is difficult to interpret. One possible explanation is that, since fine-grained soils have larger water holding capacity, increased moisture at finegrained sites could enhance litter breakdown (Williams et al., 2006). The finding by Renöfält, Nilsson \& Jansson (2005b) that substrate heterogeneity (number of substrates per reach) peaked in the middle reaches of the Vindel River where substrate was coarsest on average does not match this result. Once again, mechanisms might have differed between plot and reach scales.

In contrast to other morphological groups graminoids resisted disturbance, except in the case of litter addition. Many graminoids in the riparian zone were tuft-forming and resistant to scouring, such as Deschampsia cespitosa (L.) P. Beauv., Molinia caerulea (L.) Moench and Carex juncella + nigra. Graminoids also have a unique ability to grow after having been cut since their leaves grow from the base. Each internode on the stem has meristematic tissue (intercalary meristem) that stimulates regrowth after the grass has been damaged (Salisbury \& Ross, 1969). Xiong et al. (2001) studied a floodplain site in the Vindel River to determine the responses of riparian plants to litter accumulation. They found that litter addition reduced biomass for all graminoid species included in the study. For some species, such as Deschampsia cespitosa, the relative loss of biomass was almost $100 \%$ within a growing season. In our study, we added an amount of litter that exceeded those of Xiong et al. (2001), so treatment effects would have been even larger than those of Xiong et al. (2001).

If longitudinal variation in the general sensitivity to disturbance does not explain the responses following regulation, what then causes the inverted patterns of species richness along regulated rivers, and the different sensitivity to megaflooding in free-flowing rivers? Several possible factors that might have changed downstream can be considered, such as (1) kinds, intensities and magnitudes of disturbance, (2) recruitment of new plants and (3) disruption of dispersal. Furthermore, it is not possible to say whether the middle reaches of those regulated rivers 
investigated previously had high pre-regulation richness because the rivers were only very briefly inventoried, if at all, before impoundment.

In conclusion, we have provided evidence that disturbance plays a role in shaping riparian vegetation, but our results also suggest that it is not the most important factor in explaining the differences in the distribution of plant species density between free-flowing and regulated rivers. Many steps remain to be taken before the patterns of species richness along entire rivers can be more fully disentangled. Until then, we predict that environmental, biological and geographical (e.g. mid-domain effects) all work together in governing this vegetation which belongs among the most complex in the world.

\section{Acknowledgements}

We thank two journal reviewers for constructive comments on a previous version of the manuscript and K. Berggren, J. Bergsten, A. Duerden, V. Gählman, $N$. Häger and A. Wenngren for assisting in the fieldwork. The study was supported by grants from the Swedish World Wide Fund for Nature (to C. Nilsson).

\section{References}

Chorley R.J., Schumm S.A. \& Sugden D.E. (1984) Geomorphology. Methuen and Company, New York, USA.

Church M. (2002) Geomorphic thresholds in riverine landscapes. Freshwater Biology, 47, 541-557.

Colwell R.K. \& Lees D.C. (2000) The mid-domain effect: geometric constraints on the geography of species richness. Trends in Ecology and Evolution, 15, 70-76.

Dunn R.R., Colwell R.K. \& Nilsson C. (2006) The river domain: why are there more species halfway up the river? Ecography, 29, 251-259.

Filip G.M., Bryant L.D. \& Parks C.A. (1989) Mass movement of river ice causes severe tree wounds along the Grande-Ronde River in northeastern Oregon. Northwest Science, 63, 211-213.

Green D.M. \& Kauffman J.B. (1995) Succession and livestock grazing in a northeastern Oregon riparian ecosystem. Journal of Range Management, 48, 307-313.

Johansson M.E. \& Nilsson C. (1993) Hydrochory, population-dynamics and distribution of the clonal aquatic plant Ranunculus lingua. Journal of Ecology, 81, 81-91.
Junk W.J., Bayley P.B. \& Sparks R.E. (1989) The flood pulse concept in river-floodplain systems. Canadian Journal of Fisheries and Aquatic Sciences, 106, 110-127.

Krok T.O.B.N. \& Almquist S. (1994) Svensk Flora. Fanerogamer och Ormbunksväxter, 27th edn. Liber Utbildning, Stockholm, Sweden.

Naiman R.J., Décamps H. \& Pollock M. (1993) The role of riparian corridors in maintaining regional biodiversity. Ecological Applications, 3, 209-212.

Nilsson C. (1999) Rivers and streams. Acta Phytogeographica Suecica, 84, 135-148.

Nilsson C. \& Grelsson G. (1990) The effects of litter displacement on riverbank vegetation. Canadian Journal of Botany, 68, 735-741.

Nilsson C. \& Jansson R. (1995) Floristic differences between riparian corridors of regulated and freeflowing boreal rivers. Regulated Rivers: Research and Management, 11, 55-66.

Nilsson C., Grelsson G., Johansson M.E. \& Sperens U. (1989) Patterns of plant species richness along riverbanks. Ecology, 70, 77-84.

Nilsson C., Grelsson G., Dynesius M., Johansson M.E. \& Sperens U. (1991a) Small rivers behave like large rivers: effects of postglacial history on plant-species richness along riverbanks. Journal of Biogeography, 18, 533-541.

Nilsson C., Ekblad A., Gardfjell M. \& Carlberg B. (1991b) Long-term effects of river regulation on river margin vegetation. Journal of Applied Ecology, 28, 963-987.

Nilsson C., Ekblad A., Dynesius M., Backe S., Gardfjell M., Carlberg B., Hellqvist S. \& Jansson R. (1994) Comparison of species richness and traits of riparian plants between a main river channel and its tributaries. Journal of Ecology, 82, 281-295.

Olde Venterink H., Vermaat J.E., Pronk M., Wiegman F., van der Lee G.E.M., van den Hoorn M.W., Higler L.W.G.B. \& Verhoeven J.T.A. (2006) Importance of sediment deposition and denitrification for nutrient retention in floodplain wetlands. Applied Vegetation Science, 9, 163-174.

Pettit N.E. \& Naiman R.J. (2007) Fire in the riparian zone: characteristics and ecological consequences. Ecosystems, 10, 673-687.

Planty-Tabacchi A.-M., Tabacchi E., Naiman R.J., DeFerrari C. \& Décamps H. (1996) Invasibility of species rich communities in riparian zones. Conservation Biology, 10, 598-607.

Poff N.L., Allan J.D., Bain M.B., Karr J.R., Prestegaard K.L., Richter B.D., Sparks R.E. \& Stromberg J.C. (1997) The natural flow regime. BioScience, 47, 769-784.

Polzin M.L. \& Rood S.B. (2006) Effective disturbance: seedling safe sites and patch recruitment of riparian 
cottonwoods after a major flood of a mountain river. Wetlands, 26, 965-980.

Renöfält B.M., Jansson R. \& Nilsson C. (2005a) Spatial patterns of plant invasiveness in a riparian corridor. Landscape Ecology, 20, 165-176.

Renöfält B.M., Nilsson C. \& Jansson R. (2005b) Spatial and temporal patterns of species richness in a riparian landscape. Journal of Biogeography, 32, 2025-2037.

Renöfält B.M., Merritt D.M. \& Nilsson C. (2007) Connecting variation in vegetation and stream flow: the role of geomorphic context in vegetation response to large floods along boreal rivers. Journal of Applied Ecology, 44, 147-157.

Salisbury F.B. \& Ross C. (1969) Plant Physiology. Wadsworth Publishing Company, Belmont, California, USA.

Shafroth P.B., Stromberg J.C. \& Patten D.T. (2002) Riparian vegetation response to altered disturbance and stress regimes. Ecological Applications, 12, 107123.

Suding K.N. \& Goldberg D. (2001) Do disturbances alter competitive hierarchies? Mechanisms of change following gap creation Ecology, 82, 2133-2149.

Sundborg A., Elfström A. \& Rudberg S. (1980) Piteälven, Laisälven and Vindelälven. Environmental Effects of River Diversions and Hydropower Development. Department of Physical Geography, Uppsala University, Uppsala, Sweden.

Tabacchi E., Planty-Tabacchi A-M. \& Décamps O. (1990) Continuity and discontinuity of the riparian vegetation along a fluvial corridor. Landscape Ecology, 5, 9-20.
Tilman D. (1993) Species richness of experimental productivity gradients: how important is colonization limitation? Ecology, 74, 2179-2191.

Tockner K., Malard F. \& Ward J.V. (2000) An extension of the flood pulse concept. Hydrological Processes, 14, 2861-2883.

Vogt K., Rasran L. \& Jensen K. (2007) Seed deposition in drift lines: opportunity or hazard for species establishment? Aquatic Botany, 86, 385-392.

Ward J.V. (1998) Riverine landscapes: biodiversity patterns, disturbance regimes, and aquatic conservation. Biological Conservation, 83, 269-278.

Williams D.G., Scott R.L., Huxman T.E., Goodrich D.C. \& Lin G. (2006) Sensitivity of riparian ecosystems in arid and semiarid environments to moisture pulses. Hydrological Processes, 20, 3191-3205.

Wintle B.C. \& Kirkpatrick J.B. (2007) The response of riparian vegetation to flood-maintained habitat heterogeneity. Austral Ecology, 32, 592-599.

Wright J.F., Moss D., Armitage P.D. \& Furse M.T. (1984) A preliminary classification of running-water sites in Great Britain based on macro-invertebrate species and the prediction of community type using environmental data. Freshwater Biology, 14, 221-256.

Xiong S., Nilsson C., Johansson M.E. \& Jansson R. (2001) Responses of riparian plants to accumulation of silt and plant litter: the importance of plant traits. Journal of Vegetation Science, 12, 481-490.

(Manuscript accepted 03 June 2008) 